\title{
Determinants of crop-livestock diversification in the mixed farming systems: evidence from central highlands of Ethiopia
}

Wuletaw Mekuria ${ }^{1 *}$ and Kindu Mekonnen²

\begin{abstract}
Background: This paper devotes to determinants of crop-livestock diversification in the mixed farming systems in the Gudo Beret watershed, central highlands of Ethiopia. In the highland agro-ecologies, the mixed farming-dominated agriculture is persistently confronted with food insecurity, feed scarcity and land degradation. During heavy rains or drought periods, farmers become vulnerable to food and feed shortfalls. To fill such gaps, the government of Ethiopia has made efforts to enhance the productive capacity of soils and thereby increase productivity on diversified farms in different agro-systems. Anthropogenic and natural calamities adversely affect the livelihoods of smallholders in general and crop-livestock systems in particular. The aim of this study is to examine the determinants of crop-livestock diversification and evaluate the link between farm activities and household food supplies.
\end{abstract}

Methods: Both qualitative and quantitative data were collected from 211 randomly selected household-heads in Gudo Beret watershed, central highlands of Ethiopia. Descriptive statistics, inferential tests, and econometric models were employed for analysis.

Results: Tobit model results revealed that livestock holding is positive and significantly influence the extent of croplivestock diversification at 1\% significant level. Extension contact and irrigated land are also positive and significantly influence the extent of diversification at 5\% level, while land rent-out, improved seed and soil fertility status are negative and significantly influence the crop-livestock diversification at 1, 5, and 5\% significant levels. Ordinary least square regression results show that barley, wheat- and faba bean-based farming have positive correlation and significant effects on the household food energy, while vegetables and highland fruits production have negative correlation with the household food supply and significant at $1 \%$ level.

Conclusions: Crop-livestock diversification is the best potential livelihood strategy for farm households. Barley, wheat and faba bean are the most dominant crops that have immense contribution for human nutrition and crop residue mainly used to feed livestock. Therefore, crop-livestock producers, agricultural practitioners, the Ethiopian government and partner organizations need to give due attention for agricultural extension service, investment for supplementary irrigation and integrated mixed crop-livestock systems.

Keywords: Crop-livestock diversity, Margalef index, Mixed farming, Tobit model, Watershed

\footnotetext{
*Correspondence: wuletaw.mekuria@aau.edu.et

${ }^{1}$ Centre for Rural Development, College of Development Studies, Addis

Ababa University, P. o. b 1176, Addis Ababa, Ethiopia

Full list of author information is available at the end of the article
} 


\section{Background}

Mixed farming is a process by which farmers produce crops and rear livestock simultaneously to ensure sustainable agriculture $[1,2]$. The production of one or more crops and livestock on available resources is crop-livestock diversification [3]. Diversified farms can ensure food security, conserve biodiversity, improve dietary preference, increase household income, reduce vulnerability to shocks and create job opportunity [4-6]. Mixed production systems also enhance land productivity and improve water use efficiency [4, 7]. Farm diversification is a means to minimize risks and insurance against crop failures $[4,5,8,9]$. Various farm activities provide a wide range of responses to uncertain conditions and increase household income and resilience $[4,10]$. Households who practice crop-livestock systems have improved $50 \%$ of productivity and farm income in the highlands of Ethiopia compared to smallholders that only raise crops [4].

Many research findings maintain the theory of agricultural intensification [1, 11-14]. However, intensified farming and continuous cultivation with limited soil amendments and conservation practices resulted in soil erosion and nutrient depletion [15]. Although the experience of crop-livestock integration is an evidence for agricultural intensification, specialized cereal cultivation could not generate desired benefits for the livelihoods of households in Ethiopia [16]. Other researchers have tried to mediate the debates between farm diversification and intensification $[2,10,17,18]$. They have suggested that agricultural intensification is an appropriate strategy for large-scale, location specific and capital-intensive enterprises. It is also possible to intensify farm activities without reduction of crop and livestock components. For instance, use of high yielding varieties, fertilizers, pesticides along with soil and water conservation practices are considerable shifts from extensive traditional farming to intensive agriculture in the highlands of Ethiopia.

Subsistence consumption, source of household income, animal feed, fuel energy, export earnings, national returns and improvement of soil fertility are the major contributions of crops. Crop production is heavily dependent on climate variables, seeds, water, soil nutrients, biodiversity and technical knowledge of farmers [19]. Livestock also provide food, fuel, manure, draught power, offspring, sociocultural benefits, and transport services [20]. Ethiopia has a large livestock resource being the first in Africa and the tenth in the world [21]. In Sub-Saharan Africa, the country has the largest livestock density after Uganda in terms of cattle, sheep and goat [22]. Livestock contribute about $13-16 \%$ of export earnings [23], and $7.9 \%$ of the total gross domestic product to the national economy [24].
Maintaining the proper stocking rates on pasturelands can optimize livestock production and maximize animal health and its performance [25].

Despite mixed farming is one of the main livelihood strategies of farmers, Ethiopia has been challenged with anthropogenic and natural factors. Boserup [26] and Godfray et al. [19] confirmed that the intensity of food supply has positive correlation with population growth at different rates and increasing trends. However, in Ethiopia, the trend of production growth is immensely uneven compared to the growth of human population due to erratic nature of rainfall and susceptible to weather shocks. Favorable weather conditions of a year result in bumper harvest, whereas severe drought is an evident for crop failure that adversely affects agricultural production $[16,24]$. Population growth aggravates the competitive demands between crop production and livestock husbandry [15]. High stocking rate, low farm productivity and land degradation are the key problems in the high lands of Ethiopia [27-29].

Land degradation, food insecurity and feed scarcity are still adversely affecting the livelihoods of farmers and landscape situations of the study area [10, 30-32]. Farmlands could not produce adequate food for the rising population and exhibited large rates of malnutrition [5]. Food insecurity and lose of natural vegetation will intensify underfeeding unless increasing pressures and competing demands over the land are wisely managed [33]. Despite significant efforts have been made on mixed farming in managing production risks, studies on farm diversification in Ethiopia is minimal and largely focused on crops and incomes. To the best of our knowledge, there has been no study conducted on crop-livestock diversification in central highlands of Ethiopia. Thus, this research could provide information on determinants of diversification and its contribution for household food security. Therefore, the objectives of this study were to identify factors that influence the probability and extent of farmers' decision on croplivestock diversity and to examine the link between farm diversification and food supply in response to various adverse effects in the Gudo Beret watershed, central highlands of Ethiopia.

The next sections of the paper describe methods including area description, sampling procedures, source of data, methods of data collection, and specifications of the theoretical and empirical models. Demographic characteristics of the interviewed household-heads, regression estimates and the link between crop-livestock diversification and household food security are reported in the results and discussion parts. The paper also concludes key findings with policy recommendations. 


\section{Methods}

\section{Description of the study area}

The study was conducted in Gudo Beret watershed of the Basona district in central highlands of Ethiopia (Fig. 1). The watershed is geographically located in latitudes between $9^{\circ} 76^{\prime}$ and $9^{\circ} 81^{\prime}$ North, and longitudes $39^{\circ} 65^{\prime}$ and $39^{\circ} 73^{\prime}$ East at a distance of $160 \mathrm{~km}$ Northeast of Addis Ababa and $32 \mathrm{~km}$ Northeast of Debre Berhan town on the way to Dessie. More than $90 \%$ of the topography has medium and steep slopes. The altitude of the study area ranges between 2828 and $3700 \mathrm{~m}$ above sea level elevated from west to east. The dominant land use/cover types were cropland and woodlot followed by grazing land and bush lands. Regosols, Cambisols, and Lithosols were the three dominant soil classes that exist in the watershed [31].

The watershed is moist and cold climate zone characterized by $55.7 \%$ of Dega, and $44.3 \%$ of high Dega agro-ecologies. The mean daytime temperature ranges between $2.4{ }^{\circ} \mathrm{C}$ during winter and $19.2{ }^{\circ} \mathrm{C}$ during summer seasons. The watershed has bimodal rainfall pattern with annual rainfall between 1278 and $2060 \mathrm{~mm}$. The temperature has increased by $0.13{ }^{\circ} \mathrm{C}$ between 1995 and 2014, while the average annual rainfall has declined by $4.9 \mathrm{~mm}$ in those years. Household in the watershed practice predominantly mixed crop-livestock activities. Barley, faba bean, field pea, wheat, vegetables, potatoes, lentil, linseed, and oats were the main crops grown, while sheep, cattle, and donkey were major livestock types reared in the study area.

\section{Sampling procedures}

Two-stage sampling techniques were employed. In the first stage, the study watershed was selected purposively owing to the high livestock density and production potential for the mixed crop-livestock systems. In the second stage, 211 household-heads were selected by systematic random sampling technique in probability to proportional size. The sample size was determined and respondents were selected within the sampling frame of the study population. Interview schedule was prepared and household interview was conducted from May to July 2016.

\section{Sources of data and methods of data collection}

The primary cross-sectional data were collected from selected households through structured interview that were administered by trained enumerators. The collected data include demographic characteristics, crop species, livestock breeds, household income, biophysical features,

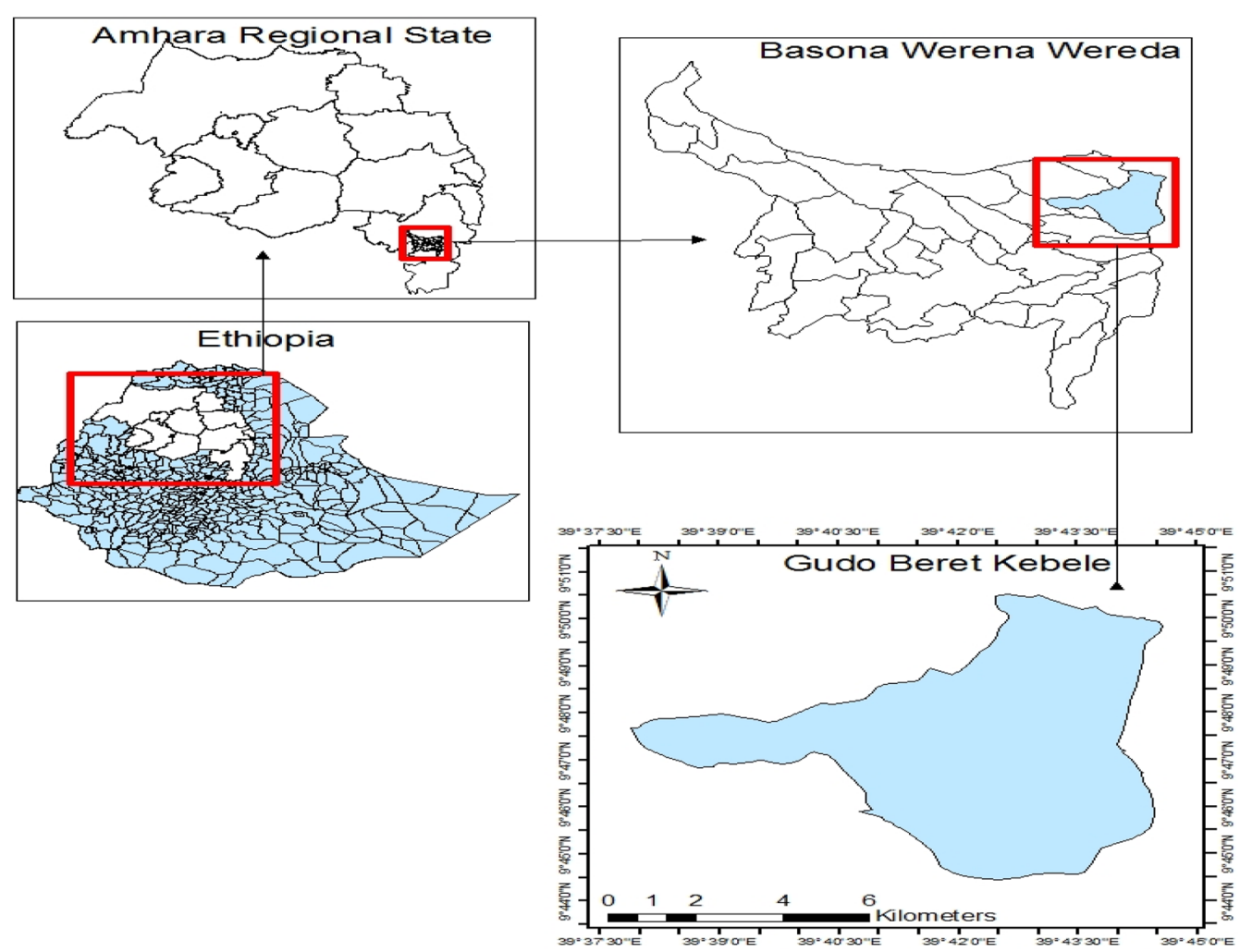

Fig. 1 Location maps of the study watershed 
infrastructures, institutions, and socioeconomics. Secondary data such as agro-climates and other supportive information were collected from office of agriculture and related empirical literatures.

\section{Methods of data analysis Theoretical model}

The utility or profit maximizing behavior was employed to analyze decisions of households [34, 35]. The assumption is that household-heads choose practices when only they want to maximize utility using diversified farms greater than monoculture. Following Greene [36], the latent utility of a $i$ th farmer for the $j$ th diversification process is denoted by $U_{j i}$, where $j=1$, otherwise 0 if the $i$ th farmer is diversify or not.

$$
D_{j}=\beta_{j} X_{i}+\varepsilon_{j} \quad \text { and } \quad D_{k}=\beta_{k} X_{i}+\varepsilon_{k}
$$

$D_{j}$ and $D_{k}$ are perceived attributes of diversified farms $j$ and $k ; X_{i}$ is the vector of independent variables that influence the perceived interest of the farms, $\beta_{k}$ and $\beta_{j}$ are parameters to be estimated and $\varepsilon_{j}$ and $\varepsilon_{k}$ are error terms assumed to be independently and identically distributed. If a farmer decides to use option $j$, it follows that the perceived utility from option $j$ is greater than the utility from other options (say $k$ ) illustrated as:

$$
D_{i j}\left(\beta_{j} x_{i}+\varepsilon_{j}\right)>D_{i k}\left(\beta_{k} x_{i}+\varepsilon_{k}\right), \quad k \neq j
$$

The probability that a farmer will use option $j$ among the set of diversified farm activities could be defined as:

$$
\begin{aligned}
& P(Y=1 / x)=P\left(D_{i j}>D_{i k}\right) \\
& P\left(\beta_{j} x_{i}+\varepsilon_{j}-\beta_{k} x_{i}-\varepsilon_{k}>0 / x\right) \\
& P\left(\beta_{j} x_{i}-\beta_{k} x_{i}+\varepsilon_{j}-\varepsilon_{k}>0 / x\right) \\
& P\left(x^{*} x+\varepsilon^{*}>0 / x\right)=F\left(\beta^{*} x_{i}\right)
\end{aligned}
$$

where $P$ is the probability function, $D_{i p}, D_{i k}$ and $X_{i}$ are as defined above, $\varepsilon^{*}=\left(\varepsilon_{j}-\varepsilon_{k}\right)$ is a random disturbance term, $\beta^{*}=\left(\beta_{i}-\beta_{j}\right)$ is a vector of unknown parameters that can be interpreted as a net influence of a vector of independent variables influencing the decision to use farm diversities, and $F^{*}\left(\beta^{x} X_{i}\right)$ is a commutative distribution function of $\varepsilon^{*}$ evaluated at $\left(\beta^{x} X_{i}\right)$. Based on this theoretical assumption, an empirical model was employed to analyze factors influencing farmers' decision on probability and extent of diversification as an important livelihood strategy.

\section{Specification of the empirical model}

Descriptive statistics (frequency, mean, standard deviation), inferential tests (Chi-square test and $t$ test), and econometric models were used to analyze the collected data. Descriptive methods were employed to describe households, livestock types, crop species, and diversification indices. Subsequent to descriptive analysis, the Tobit econometric model was employed to identify determinants of crop-livestock diversification. In addition, ordinary least square was employed to identify farm activities that influence dietary food energy. Excel, Statistical Package for Social Sciences (SPSS) version 20 and Stata Version 12 were used for data analysis.

Measuring crop-livestock diversification In order to compute a particular crop and livestock of interest, we adapted index for crop-livestock diversification. Margalef index was employed to measure crop-livestock diversification owing to some advantages compared to other indices. The index has a good discriminating ability and better goodness of fit [37]. It can capture different units of animal and plant species [38-41]. The formula was adapted in Magurran [42].

$$
D_{\mathrm{Mg}}=\frac{S-1}{\ln (N)}
$$

where $D_{\mathrm{Mg}}$ is Margalef index; $S$ is the total number of each crop species planted and livestock types reared by a household; $N$ is number of individuals, i.e., cropland and total count of animals held by a household; ln is the natural logarithm.

If the value of Margalef index is zero, a household tends to specialize in very few numbers of crop species per limited land or number of animals per total population. In other words, the value zero indicates complete specialization and a value greater than zero denotes some measures of diversification [39]. Ten types of crops (barley, wheat, faba bean, field pea, lentil, linseed, vegetables, potato, oats, and highland fruits) and eleven livestock types (cow, ox, bull, heifer, calf, sheep, goat, horse, donkey, mule, and poultry) were commonly practiced in the study area. The Margalef index is left censored for the value of $N$ equal to one because any number divided by the natural logarithm, $\ln (1)$, is undefined (Eq. 4). In order to avoid such problems, crops grown were computed in terms of meter square and number of animals in number.

Determinants of crop-livestock diversification The generated information in modeling supports household decisions and serves for early warning systems in agriculture. Logit and Probit econometric models explain only probabilities of independent variables on non-continuous dependent variables [14]. Ordinary least square regression also only ascertain relationships between many independent and single continuous dependent variables, but one could not be sure about the underlying casual mechanisms [43]. The linear regression (ordinary least square-OLS) model would apply if all households diversified their crop-livestock activities. 
In the study area, not all households participated in diversified farm activities. Hence, ordinary least square was assumed to create a sample selectivity bias because the model can exclude non-diversifiers from analysis [39]. Therefore, Tobit model is an appropriate model for censored data that gives joint decisions of probability and intensity as the same time [44-46], regardless of the number of censored observations.

The concern of this study was analysis of diversification among diversifiers and non-diversifiers. If the dependent variables were two or more diversification patterns, the most appropriate model could be a multivariate seemingly unrelated regression model. In the study area, the majority of households were diversifiers, while the least part of households were non-diversifiers due to several reasons. Examining factors among diversifiers and non-diversifiers help to suggest solutions for policymaking. The limited dependent variable regression model (Tobit) was specified to estimate the joint estimates of factors affecting crop-livestock diversification and a set of independent variables. The formula is adapted in Greene [36].

$$
\begin{aligned}
Y_{i}^{*} & =\beta x_{i}+u_{i} \\
y_{i} & =y_{i} * \quad \text { if } \quad y_{i}^{*}>0 \\
& =0 \quad \text { if } \quad y_{i}^{*} \leq 0
\end{aligned}
$$

$Y_{i}$ is observable and $y^{*}$ is latent dependent variable. A latent variable can be observable whenever it is positive. Once the latent variable is negative, the observation becomes censored, and one can simply observe, $y=0$. In this study, the data are left-censored. The subscript $i$ run from 1 to $n$ which was used to index the observations of a sample. The total number of observations denoted by $n$. $X_{i}$ is the vector of independent variables, $\beta$ is a vector of unknown coefficient, and $u_{\mathrm{i}}$ is an independent distributed error term or unobservable variable that affect $y$ assumed to be normal with a mean zero and constant variance. However, $y_{i}^{*}$ is observed if $y_{i}^{*}>0$ and is not observed if $y_{i}^{*} \leq 0$. Then, the observed $y_{i}$ is defined as:

$$
\begin{gathered}
Y_{i}=y_{i}^{*}=\beta x_{i}+u_{i} ; \quad \text { if } \quad y_{i}^{*}>0 \quad i=1,2,3 \\
0 \quad \text { if } \quad y_{i}^{*} \leq 0
\end{gathered}
$$

where $Y_{i}$ is observed dependent variable, in this case the value of diversity; $X_{i}$ is independent variables affecting the dependent variable and its intensity; $\beta$ is coefficients, and $u_{i}$ are residuals that are independently and normally distributed with mean zero and a common variance. The model parameters were estimated by maximizing the Tobit likelihood function.

$$
L=\prod_{y>0} f \frac{1}{\sigma}\left(\frac{y_{i}-\beta x_{i}}{\sigma}\right) \prod_{y \leq 0} F\left(-\frac{\beta x}{\sigma}\right)
$$

where $f$ and $F$ are the distribution and density function of $y_{i}^{*}$, respectively; $\prod_{y \leq 0}$ is product over those $i$ for which $y i * \leq 0$ and $\prod_{y>0}$ is the product over those $i$ for which $y i *>0$.

In the model, the independent variables were computed in terms of probability and intensity marginal effects. The change in explanatory variables $\left(X_{i}\right)$ affects the conditional mean of $Y_{i}$ in the positive part of the distribution and the probability that the observation fallen in that part of the distribution. The marginal effect on the latent dependent variable is expressed as:

$$
y^{*} \frac{\partial E\left(Y_{i}\right)}{\partial X_{i}}=F(z) \beta_{i} \quad \text { where, } \frac{\beta_{i} X_{i}}{\sigma} \text { is denoted by } z
$$

The other marginal effect is an independent variable on the actual value of the dependent variable. In this case, the probability of an observation is different from zero. Thus, the reported Tobit coefficients show a one-unit change in an independent variable $\left(X_{i}\right)$ alters the latent (censored) dependent variable.

Marginal effect on the expected value for $y$ (censored and uncensored); the change in the probability of a dependent variable, i.e., changes in the dependent variable as independent variable $X_{i}$ change was:

$$
\frac{\partial E(y)}{\partial x k}=\Phi\left(\frac{X_{i} \beta}{\delta}\right) \beta k
$$

Marginal effects on the expected value of $y$ for uncensored observation; the change in intensity of a dependent variable with respect to a change in an independent variable among diversifiers explained as follows. This indicated how a one-unit change in an independent variable $x k$ affected uncensored observation.

$$
\frac{\partial E[y / y>0]}{\partial x k}=\beta k\left[1-\lambda(\alpha)\left(\frac{X_{i} \beta}{\delta}+\lambda(\alpha)\right]\right.
$$

Description of variables used for analysis Crop-livestock diversification is the dependent variable computed using Margalef index. The ranges of weighted indices for crop-livestock diversity were from 0 to 1.0. A list of independent variables were identified and selected based on the previous empirical literatures and available database, which were expected to influence the choices of diversification decisions [3, 14, 39, 47, 48]. 
Variance inflation factor (VIF) was employed to test multicollinearity for continuous and contingency coefficient (CC) for discrete independent variables. Collinearity occurs when two or more variables are highly correlated and have the same effect on the dependent variable [49]. Highly correlated variables have high standard errors, low t-ratios, and wide confidence intervals in regression [44]. The minimum cutoff points for $\mathrm{CC}$ and VIF are 0.75 and 10, respectively [50]. There was no multicollinearity problem among discrete independent variables. However, there was a problem of collinearity between distance to the nearest market place and distance to the Kebele office from the residence of households. Of the two collinear variables, distance to the market place was excluded from analysis because its VIF value was higher than distance to the Kebele office. Demographic, economic, institutional, biophysical, and social factors are presented in Table 1.

Household food balance Prior to analyze the link between household food supply and farm activities, availability of food was measured. Food balance model was employed to compute the net available food in calories. The analytical method was adapted from FAO-WFP [51]. The data were collected through household survey except post-harvest losses. Robin [52] has estimated postharvest loss of grain crops in Ethiopia from 1994 to 2010, in which the crop yield was estimated with $10 \%$ loss. The quantity of estimated food supply was converted from $\mathrm{kg}$ to equivalent calories for each household. Household food balance model is expressed as:

$$
N_{i j}=\left(O_{i j}+P_{i j}+R_{i j}+A_{i j}\right)-\left(L_{i j}+S_{i j}+M_{i j}+T_{i j}\right)
$$

where $N=$ net available food; $O=$ own produced; $P=$ food purchased; $R=$ food obtained through remittance or gift; $A=$ food received through food aid; $L=$ food loss to household; $S=$ crops reserved for seed at home; $M=$ amount of food marketed or sold; and $T=$ food transfer to others. Estimations (Eq. 11) were made for total food of household $i$ in a given year $j$. The

Table 1 Hypothesized variables, descriptions, and measurements in relation to crop-livestock diversity Source: Asante et al. [3]; Manyong et al. [14]; Rehima et al. [39]; liyama et al. and Obayelu et al. [47, 48]

\begin{tabular}{|c|c|c|c|}
\hline Acronyms of variables & Variable class & Variables, units and measurement & $\begin{array}{l}\text { Hypothesized } \\
\text { Sign }\end{array}$ \\
\hline \multicolumn{4}{|l|}{ Dependent variable $\left(Y_{j}\right)$} \\
\hline Crop-livestock diversity & Continuous & Crop-livestock diversification index & \\
\hline \multicolumn{4}{|l|}{ Independent variable $\left(X_{i}\right)$} \\
\hline AGE & Continuous & Age of a household head in years & $(-/+)$ \\
\hline SEX & Discrete & Household head, $1=$ male, $0=$ female & $($ Male +) \\
\hline EDUC & Discrete & Education in year of schooling & $(+)$ \\
\hline HHLAB & Continuous & Household labor in adults & $(+)$ \\
\hline LAND & Continuous & Size of land in ha & $(-)$ \\
\hline LIVES & Continuous & Livestock holding in TLU & $(+)$ \\
\hline NONFINC & Continuous & Annual non-farm income, ETB yr ${ }^{-1}$ & $( \pm)$ \\
\hline FINC & Continuous & Annual farm income, ETB yr ${ }^{-1}$ & $( \pm)$ \\
\hline LROUT & Continuous & Land rent-out in ha & $(-)$ \\
\hline OFERT & Continuous & Amount of organic fertilizer used in ton & $(+)$ \\
\hline$|R R| G$ & Continuous & Cultivated irrigation land in ha & $(+)$ \\
\hline IFERT & Continuous & Inorganic fertilizer applied in kg & $(+)$ \\
\hline IMPSEED & Continuous & Improved seed in kg & $(+)$ \\
\hline CREDIT & Discrete & Access to credit, Yes $=1, \mathrm{No}=0$ & $(+)$ \\
\hline EXTCONT & Continuous & Extension contact in days per month & $(+)$ \\
\hline LTSECUR & Discrete & Land tenure security Yes $=1,0$ otherwise & $($ Secure +$)$ \\
\hline SOIL & Discrete & Fertility of soil (high, medium, or low) & + \\
\hline DMKT & Continuous & Distance to the local market in $\mathrm{hr}$ & $(-)$ \\
\hline DROAD & Continuous & Distance to the asphalt road in $\mathrm{hr}$ & $(-)$ \\
\hline DKEBELE & Continuous & Distance to the Kebele office in $\mathrm{hr}$ & $(-)$ \\
\hline SLOPE & Discrete & Slope class (steep, medium, flat) & $(-/+)$ \\
\hline SOCIAL & Discrete & Social status, Yes $=1, \mathrm{No}=0$ & $(+)$ \\
\hline
\end{tabular}


available food items include grains, potato, vegetables, fruits, and animal products (milk, meat, egg, and honey).

To find out the link between diversified farm activities and household food supplies, ordinarily least squares regression was employed. The model was specified after farm activities measured in standardized units using $\mathrm{Z}$-score and household food energy quantified in calories.

$$
Y_{i}=\beta_{0}+\beta_{1} X_{i 1}+\cdots \beta_{n} X_{i n}+\varepsilon
$$

where $Y_{i}=$ household food energy in calories; $X_{i}=$ farm activities for $i$ th farmers; $\beta_{0}=$ intercept; $\beta_{1} \cdots \beta_{n}=$ are coefficients; and $\varepsilon=$ the error term.

\section{Results and discussion}

\section{Descriptive statistics}

Nearly $29 \%$ of households were female-headed. About $21 \%$ of the household-heads were illiterate, whereas $43 \%$ of the household-heads were at least able to read and write. The average size of household members was 4-5 and 3.9 adult equivalents per household. The average sizes of farmlands and livestock holdings were 1.2 ha and 4.0 TLU per household. Almost every household produced annual crops, while $94 \%$ of households reared livestock in the study watershed. Households in the study area keep cattle, equine, sheep and goat, or some combinations of these as well as cultivate crops. Crop production, animal husbandry, forestry, non-farm and off-farm activities are the main livelihood strategies of smallholders. The proportions of crops and livestock holdings varied among farmers according to growth potentials, socioeconomic attributes and biophysical factors. The mean crop-livestock production diversity of the study area (8.76) was lower than (10.2) the national average [41].
Three-quarters of the cattle population were indigenous breeds, while $25 \%$ were improved breeds. Oxen were the highest cattle population, while sheep were the highest number in livestock population. Sheep and chicken were the predominant livestock types in number followed by ox, donkey and cow. Cattle were the leading livestock population (61\%) followed by $20 \%$ of sheep and goat, $18 \%$ of equines and $1 \%$ of poultry in terms of TLU (Fig. 2).

In this study, diversifiers refer to households who produced more than one crop or livestock activities, while non-diversifiers represent households who did not grow crops and/or rear animals, or they produced only a single enterprise in the crop-livestock production systems. The $\chi^{2}$ test showed that there was no statistical difference between diversifiers and non-diversifiers on discrete independent variables. The $t$ test results revealed that the mean differences for some continuous independent variables were statistically significant between diversifiers and non-diversifiers at different probability levels. The most continuous independent variables have had larger mean differences for diversifiers than non-diversifiers except non-farm income and extension contact (Table 2). Age of household head, farm income and livestock were statistically significant at $1 \%$ probability levels, while improved seed was significant at $5 \%$ level.

\section{The distribution of diversification index}

Our result indicated high degree of diversification. The average crop-livestock diversification index was 0.57 with standard deviation of 0.22 . The average crop-livestock diversification index of this study was almost comparable with the finding of Asante et al. [3] found 0.59 in Ghana. Figure 3 depicted normal distribution in
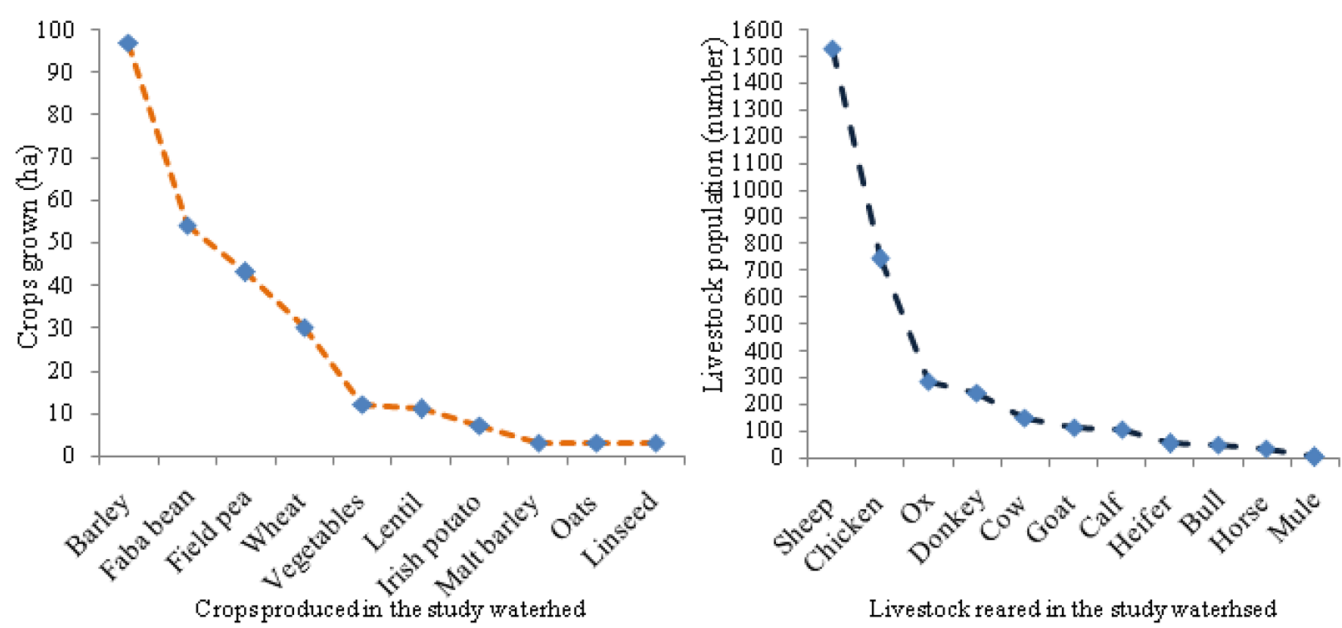

Fig. 2 Crop-livestock distributions 
Table 2 Summarized descriptive statistics for independent variables by sample farmers

\begin{tabular}{|c|c|c|c|c|c|}
\hline Variable acronyms & Total mean $(N=211)$ & $\begin{array}{l}\text { Diversifiers mean } \\
(N=207)\end{array}$ & $\begin{array}{l}\text { Non-diversifiers mean } \\
(N=4)\end{array}$ & $t / \chi^{2}$ test & $p$ value \\
\hline AGE & 43.8 & 43.9 & 37.8 & $-5.100^{* * *}$ & 0.000 \\
\hline SEX+ & 68.7 & 67.8 & 0.9 & 0.665 & 0.591 \\
\hline EDUC + & 79.2 & 77.3 & 1.9 & 1.074 & 0.582 \\
\hline HHLAB & 2.8 & 2.8 & 1.9 & $-2.499^{*}$ & 0.078 \\
\hline LAND & 1.3 & 1.4 & 0.7 & $-2.727^{*}$ & 0.068 \\
\hline LIVES & 4.0 & 4.1 & 0.6 & $-12.370^{* * *}$ & 0.000 \\
\hline NONFINC & 944.8 & 916.0 & 2437.5 & 1.059 & 0.366 \\
\hline FINC & 3892.6 & 3955.8 & 625.0 & $-6.490^{* * *}$ & 0.000 \\
\hline LROUT & 0.1 & 0.1 & 0.0 & -1.103 & 0.323 \\
\hline OFERT & 87.4 & 88.5 & 31.3 & $-2.850^{*}$ & 0.055 \\
\hline IRRIG & 0.0 & 0.0 & 0.0 & -0.465 & 0.465 \\
\hline IFERT & 61.3 & 61.7 & 37.5 & -0.996 & 0.388 \\
\hline IMPSEED & 15.6 & 15.9 & 3.8 & $-2.781^{* *}$ & 0.035 \\
\hline CREDIT† & 40.3 & 39.8 & 0.5 & 0.396 & 0.650 \\
\hline EXTEN & 1.3 & 1.3 & 1.5 & 0.717 & 0.717 \\
\hline LTSECUR† & 47.4 & 46.5 & 0.9 & 0.011 & 0.449 \\
\hline SOIL† & 86.3 & 84.9 & 1.4 & 0.436 & 0.627 \\
\hline DROAD & 18.4 & 18.6 & 9.8 & -0.286 & 0.286 \\
\hline DKEBELE & 28.0 & 28.3 & 14.3 & $-0.093^{*}$ & 0.093 \\
\hline SLOPE† & 5.7 & 5.7 & 0.0 & 0.246 & 0.620 \\
\hline SOClAL† & 25.2 & 24.2 & 0.9 & 1.342 & 0.263 \\
\hline
\end{tabular}

$* * * * *,{ }^{*}$ Significant at 1,5 , and $10 \%$; $†$ is designated for discrete independent variables

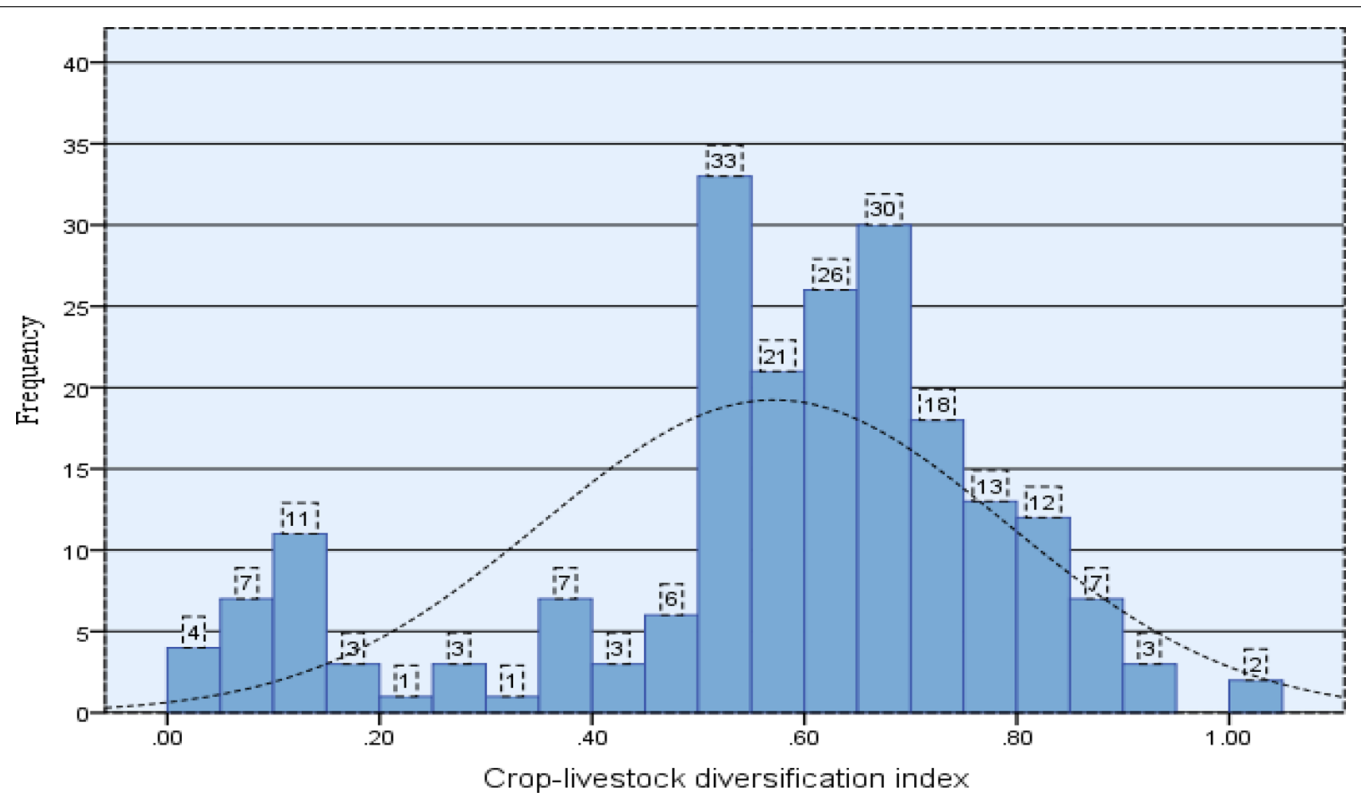

Fig. 3 Distribution of crop-livestock diversification index

crop-livestock diversification though it was moderately skewed to the left. More than three-fourth (79\%) of the households having indices 0.5 and above, suggest a high level of crop-livestock diversification among farmers.
The estimated index was significant among diversifiers ( $t$ value $=-5.471 ; p<0.01$ ).

Nearly $98 \%$ of households have diversified crop-livestock activities and $58 \%$ of them have practiced higher 
than the mean index of diversifiers. Limited number of households (2\%) did not diversify farm activities, because of landlessness, labor dependency or specialized in monoculture. It implies that the level of diversification was quite diverse among household. Variations for proportions of crop-livestock activities might happen due to differences in farm resources, priorities of the farm activities, and ability to manage their available resources. These conditions forced them not to look for ways to engage them in diversified activities. As a result, they have rented out their land and involved in non-farm activities with or without producing a particular crop or a single animal. The diversity of livestock $(0.86 \pm 0.39)$ was tremendously higher than the diversity of crops $(0.28 \pm 0.12)$ with reasonable symmetrical distribution. About $6.2 \%$ of households did not own livestock and other $4.7 \%$ of households specialized in a single animal. Similarly, $0.9 \%$ of the households did not produce crops and other $3.8 \%$ of the producers specialized in growing only a single crop.

Households were classified into three equal parts based on crop-livestock diversification index. The average indices of the lower, middle and high categories were 0.17 , 0.54 , and 0.80 . About 14,54 , and $32 \%$ of the households have diversified their activities in the lower, middle, and high category of indices. The ages of $61 \%$ households were between 31 and 50 years. The highest age of diversity index was between 31 and 40 years. Majority of (60\%) the female-headed households were in the lower category. High proportion of households (77\%) held farmlands less than 1.3 ha within the lower category. Almost half of the farmers accessed farmlands on average 0.8 ha. Three-quarters (77\%) of households possessed $\geq 1.0$ ha of land, while $18 \%$ of farmers held between 0.5 and 1.0 ha of land. Five percent of households held $<0.5$ ha of land. Household-heads with educational level of grade 9 and above were $5 \%$ (Table 3 ).

\section{Determinants of farm diversification}

The Tobit model output suggests that land holding size, livestock, non-farm income, land rented-out, irrigated land, extension contact, soil fertility, road distance, Kebele distance, and improved seed aer the major factors significantly affected crop-livestock diversification. After Tobit regression, marginal effects were computed. The parameter estimates of latent coefficients and marginal effects of the latent variable for continuous decision in Tobit regression were almost similar. Sichoongwe et al. [43], Dube and Guveya [53] reported that coefficients of the probability and intensity of Tobit results are the same. Latent coefficients showed directions and level of significance for each independent variable, while marginal effects indicated not only directions and level of significance, but also offered information regarding probabilities and extent of influence on the dependent variable. The probability coefficients revealed the likelihood of diversity in the discrete choice of crop-livestock diversification. The regression results in Table 4 indicated that the probability coefficients for diversification attributed by the independent variables were insignificant. Because, the likelihood of households to diversify their crop-livestock activities was $99.9 \%$, that showed insignificant difference from the descriptive results (98\%).

It implies the contribution of independent variables to the choice of decisions on crop-livestock diversification was less important. One of the main reasons could be the limited number of households who did not diversify their farm activities. The intensity coefficients for some independent variables were significant among diversifiers. Altogether, $81 \%$ of the households could diversify their farm activities more than the constant value (0.41) owing to independent variables. Thus, intensity coefficients infer how a one-unit change in an independent variable alters the dependent variable of crop-livestock diversity.

\section{Farm size}

More land size increased the capacity of farmers to diversify farm activities. As -anticipated, landholding size is found to have positive relationship and significant effect $(p<0.1)$ on the extent of diversification though the probability of diversity is insignificant. An additional unit of land can increase the probability of diversification by $0.1 \%$. It means that as land size increases by one ha, crop-livestock diversification increases by $5.1 \%$. An increase in land size could increase the index category of crop-livestock diversification. For example, a farmer having an index of 0.33 in lower category can increase to 0.35 of the middle category if the land size increases by one ha. This means, more landholdings enabled farmers to allocate their farm activities in multiple productions than small farms to minimize production risks. This result is consistent with the findings of many studies [3, $39,43,54]$. However, the possibility of getting more land is unlikely unless a household acquires through rent-in, inheritance, or sharecropping.

\section{Non-farm income}

This variable influenced the continuous decision of diversification negatively and significantly $(p<0.1)$. Getting more non-farm income was unlikely to diversify croplivestock activities. As non-farm income increases by one birr, the crop-livestock diversity decreases by less than $1.0 \%$. Thus, the extent of decrease in diversity due to nonfarm income was negligible. Higher incomes from nonfarm activities could affect the interest of farmers and led to divert their resources away from farming. Previous 
Table 3 Basic characteristics of crop-livestock diversifiers by Margalef index

\begin{tabular}{|c|c|c|c|c|}
\hline \multirow{2}{*}{ Socioeconomic characteristics } & \multicolumn{4}{|l|}{ Index } \\
\hline & $0.0-0.33(N=30)$ & $0.34-0.67(N=114)$ & $0.68-1.00(N=63)$ & Total $(N=211)$ \\
\hline \multicolumn{5}{|l|}{ Age of household head (years) } \\
\hline$<30$ & 23.3 & 13.2 & 15.9 & 15.5 \\
\hline $31-40$ & 33.3 & 29.8 & 34.9 & 31.9 \\
\hline $41-50$ & 30.0 & 33.3 & 20.6 & 29.0 \\
\hline $51-60$ & 6.7 & 14.0 & 17.5 & 14.0 \\
\hline Above 61 & 6.7 & 9.7 & 11.1 & 9.6 \\
\hline Total & 100.0 & 100.0 & 100.0 & 100.0 \\
\hline \multicolumn{5}{|l|}{ Sex of household head } \\
\hline Male & 40.0 & 71.0 & 77.8 & 68.6 \\
\hline Female & 60.0 & 29.0 & 22.2 & 31.4 \\
\hline Total & 100.0 & 100.0 & 100.0 & 100.0 \\
\hline \multicolumn{5}{|l|}{ Size of landholding (ha) } \\
\hline $0.0-1.30$ & 76.7 & 45.6 & 44.4 & 49.8 \\
\hline $1.31-2.60$ & 23.3 & 51.8 & 52.4 & 47.8 \\
\hline $2.60-4.00$ & 10.0 & 2.6 & 3.2 & 2.4 \\
\hline Total & 100.0 & 100.0 & 100.0 & 100.0 \\
\hline \multicolumn{5}{|l|}{ Household labor (AE) } \\
\hline $0.0-2.30$ & 63.3 & 47.4 & 46.0 & 49.3 \\
\hline $2.31-4.60$ & 23.3 & 41.2 & 42.9 & 39.1 \\
\hline $4.61-6.90$ & 13.4 & 11.4 & 11.1 & 11.6 \\
\hline Total & 100.0 & 100.0 & 100.0 & 100.0 \\
\hline \multicolumn{5}{|l|}{ Livestock holding (TLU) } \\
\hline $0.0-4.20$ & 100.0 & 40.4 & 50.8 & 52.2 \\
\hline $4.21-8.40$ & 0.0 & 51.8 & 42.9 & 41.6 \\
\hline $8.41-12.6$ & 0.0 & 7.8 & 6.3 & 6.2 \\
\hline Total & 100.0 & 100.0 & 100.0 & 100.0 \\
\hline \multicolumn{5}{|l|}{ Education (years of schooling) } \\
\hline Not literate & 30.0 & 20.2 & 19.1 & 21.3 \\
\hline Grade 1-4 & 33.3 & 63.2 & 57.1 & 57.0 \\
\hline Grade 5-8 & 23.3 & 13.2 & 19.1 & 16.4 \\
\hline Grade 9-12 & 10.0 & 2.6 & 4.7 & 4.3 \\
\hline Diploma and above & 3.4 & 0.8 & 0.0 & 1.0 \\
\hline Total & 100.0 & 100.0 & 100.0 & 100.0 \\
\hline
\end{tabular}

Size of landholding, household labor, and livestock holding are classified into three (low, middle, and high) categories

studies have found that non-farm/off-farm income per capita has non-harmonious effects. It could have either negative or positive influence on diversification [3] depending on the amount of return and extent of farmers' engagement. Our finding was consistent with studies conducted in Indonesia, India, Zimbabwe, Ethiopia, Kenya, Ghana and Nigeria on farm and livelihood diversifications [3, 41, 51, 55]. Asante et al. [3] have found that off-farm income has positive and significant influence on the probability of crop-livestock diversity, whereas their finding revealed that the extent of diversification caused by non-farm income is negative.

\section{Livestock}

This variable had positive and significant influence on probability $(p<0.1)$ and intensity $(p<0.01)$ of crop-livestock diversity in the farming systems. As livestock size increases by one TLU, the level of diversification increases by $3 \%$. The positive coefficient of this result is similar with other findings $[14,51]$. 
Table 4 Tobit regression results for determinants on croplivestock diversity

\begin{tabular}{|c|c|c|c|c|}
\hline \multirow[t]{2}{*}{ Variables } & \multicolumn{4}{|c|}{ Marginal effects } \\
\hline & Prob. coef. & P-level & Inten. coef. & P-level \\
\hline AGE & 0.0000 & 0.366 & 0.0012 & 0.319 \\
\hline EDUC† & -0.0005 & 0.390 & -0.0295 & 0.410 \\
\hline SEX† & 0.0010 & 0.883 & 0.0048 & 0.881 \\
\hline LAND & 0.0010 & 0.173 & $0.0510^{*}$ & 0.076 \\
\hline HHLAB & -0.0002 & 0.420 & -0.0099 & 0.384 \\
\hline FINC & -0.0000 & 0.310 & -0.0000 & 0.250 \\
\hline NONFINC & -0.0000 & 0.179 & $-0.0000^{*}$ & 0.083 \\
\hline LIVES & $0.0006^{*}$ & 0.062 & $0.0302^{* * *}$ & 0.000 \\
\hline OFERT & -0.0000 & 0.396 & -0.0002 & 0.356 \\
\hline LROUT & $-0.0034^{*}$ & 0.093 & $-0.1715^{* * *}$ & 0.007 \\
\hline CREDIT† & 0.0004 & 0.523 & 0.0005 & 0.513 \\
\hline IFERT & 0.0000 & 0.484 & 0.0001 & 0.458 \\
\hline EXTEN & 0.0006 & 0.130 & $0.0309^{* *}$ & 0.032 \\
\hline IRRIG & 0.0083 & 0.133 & $0.4267^{* *}$ & 0.035 \\
\hline SOCIAL† & 0.0009 & 0.170 & 0.0544 & 0.127 \\
\hline SOIL† & $-0.0011^{*}$ & 0.082 & $-0.0880^{* *}$ & 0.027 \\
\hline DROAD & -0.0000 & 0.176 & $-0.0021^{*}$ & 0.079 \\
\hline DKEBELE & 0.0000 & 0.157 & $0.0019^{*}$ & 0.059 \\
\hline SLOPE† & -0.0012 & 0.595 & -0.0439 & 0.460 \\
\hline SEED & -0.0000 & 0.143 & $-0.0010^{* *}$ & 0.045 \\
\hline LTSECUR† & 0.0005 & 0.454 & 0.0254 & 0.423 \\
\hline -cons & $0.4148^{* * *}$ & & & \\
\hline \multicolumn{5}{|c|}{4 observations are left censored } \\
\hline \multicolumn{5}{|c|}{ Log likelihood $=49.14 ; L R x^{2}=83.36(p$ value $=0.000)$} \\
\hline \multicolumn{5}{|c|}{ Pseudo $R^{2}=-5.59$} \\
\hline
\end{tabular}

Significant level ${ }^{* *}(p<0.01), * *(p<0.05)$, and ${ }^{*}(p<0.1)$ and + denotes discrete variables

\section{Land rent-out}

According to descriptive statistics, a small number of farmers (7\%) were dependent on land rent-out for their subsistence of food demands. Land rent-out was negative and significant on crop-livestock diversity. As a household increases land rent-out by one ha, the probability of diversity declines by $0.3 \%(p<0.1)$. The intensity of croplivestock diversity also decreases by $17.2 \%(p<0.01)$. A household that rented out his/her land was not likely to diversify farm activities, as he/she had to use the land to produce more crops and harvest forage or keep animals on it. According to Daniel et al. [55], land transfer adversely affects long-term investment in agriculture and results in low returns. The same authors have substantiated that transfer rights and threats of expropriation influence negatively long-term investments in agriculture that perpetuate low growth and poverty. Otsuka [56] also reported that land use rights and strengthening of land tenure security in Ethiopia enhance the incentives of farm households to invest more in the acquisition of new knowledge and land improvements.

\section{Extension service}

Agricultural extension service is found to have significant $(p<0.05)$ and positive effect on the extent of croplivestock diversification. As extension contact increases by 1 day in monthly bases, the level of crop-livestock diversification increases by $3 \%$. Households who gained knowledge and acquired skill from development agents might optimistically influence the intensity of croplivestock diversification. Evidences from other empirical studies revealed that extension service has mixed effects on crop-livestock diversification. Rehima et al. [39] and Asante et al. [3] pointed out that extension service has significant contributions in increasing different farm enterprise options. Our finding contradicted with Wondimagegn [50] who found that the frequency of contact of development agents has adverse effects on farm diversities.

\section{Irrigation land}

An increase in irrigation land is found to have positive and significant influence on the extent of crop-livestock diversity $(p<0.05)$. Small-scale irrigation used to grow vegetables, animal feed, and some grain crops such as lentil. Irrigation enables to increase crop-livestock diversity as it supplement water at the time of rain shortage. Other studies also reported similar findings [21, 51]. Moisture retained through irrigation can increase both the probability and intensity of crop-livestock diversification [14]. Access to irrigable lands may not necessarily suggest area expansion. It could be the use of stored moisture and increasing the frequency of cropping per year on existing lands.

\section{Soil fertility}

The model result showed that soil fertility is a biophysical factor found to have negative relationship between the probability $(p<0.1)$ and intensity $(p<0.05)$ of diversification. As poor soils change to fertile status, a decision on the probability and intensity of diversification declines by $0.1 \%$ and $8.8 \%$, respectively. According to the household survey and field observation, farmers were more likely to practice diversified farms on degraded plots than fertile lands. Households who own fertile lands could not motivated to diversify more crops and livestock activities rather they want to produce crops that are more profitable. Some researchers $[39,51]$ reported similar findings that fertile soils reduce the extent of crop diversification because fertile plots tend to be specialized on limited varieties. Households in Gudo Beret have grown diverse crops and eucalyptus trees to diversify household 
incomes. The relationship between organic fertilizer and diversification was also negative though its level of probability was insignificant. It implies that soils that are more fertile grow crops with low level of diversity. Households tend to cultivate only crops as long as the crops provide high returns for subsistence needs regardless of marketing opportunities and nutritional benefits.

\section{Road distance}

The extent of influence of road distance on crop-livestock diversity was negative and significant $(p<0.1)$. Short distance between household's residence and the main tarmac road had favorable effect on the crop-livestock diversity. Households dwell far away from the main road were less likely to diversify crop-livestock activities. The result revealed that the extent of diversity declines by $0.2 \%$ as a farmer travels 1 -min of time. Various farm activities such as irrigation, seedling nurseries, and other infrastructures are located near to the main asphalt road. Ashfaq et al. [55] have found similar results in India where road distance affects farm diversification negatively and significantly. Road distance is negative on crop diversity though the extent of influence is insignificant in eastern and southern parts of Ethiopia $[39,50]$. Households reside in near to the main road reduce transport and marketing costs. Farmers located farther away from the main road might produce only to meet their subsistence and nutritional needs [3, 43]. Various findings reported unlike relationship between road distance and crop diversification in accordance with the nature of crop production [43].

\section{Kebele distance}

The time of travel from household's residence to the nearest Kebele office affected the intensity of crop-livestock diversification positively and significantly $(p<0.1)$. An increase in time in 1-min travel between household's residence and the Kebele office, the extent of diversification increases by $0.2 \%$. The effect of distance between Kebele office and household's residence is positive in relation to some crops and negative on other crops grown in Nigeria [46]. In our study, most of households settled near to the centre of the Kebele, employed in non-farm/off-farm activities. Some households who reside adjacent to Gudo Beret town have limited farmlands and involved in nonfarm activities. The nature of settlement patterns close to the town is highly populated and less likely to obtain adequate grazing fields and croplands. The other probable reason for positive relationship between distance to the office and farm diversification is social and administrative responsibilities. One-quarters of household-heads have had different social responsibilities being involved in administrative and social obligations. Those households who played social and political affairs and settled near to the office might have limited participations on diversified farm activities.

\section{Improved seed}

The improved crop seed cultivars had negative effect on the discrete and continuous decisions of crop-livestock diversity, suggesting that it is less important for subsistence producers. The likelihood of a household to diversify crop-livestock activities attribute to improved seed was not significant. Even though improved seed is significant $(p<0.05)$ on the crop-livestock diversity, the extent of influence was not considerable. As improved seed variety increases by one $\mathrm{kg}$, the extent of crop-livestock diversity decreases by $0.1 \%$. The probable reason for negative relationships could be households tend to use improved seeds may give less attention to livestock as a result crops compete with livestock for land resources. In addition, high cost and delay to access for improved seed imply adverse effects on diversification.

The results of relationship between the dependent variable and some independent variables were contrasted with prior hypotheses. Age, sex, credit, fertilizer, social status, and land tenure security were positive with croplivestock diversity though they are insignificant. Positive relationship of age with crop-livestock diversity implies extent of diversification is higher among older householdheads. The positive result for fertilizer is in agreement with many studies $[39,43]$. The coefficients for education, household labor, farm income, and slope of farmlands were negative with crop-livestock diversity. It implies the household labor did not affect the level of crop-livestock diversity [3]. In this study, education is negative but insignificant on diversification. Several reports also noted that education has negative relationships with farm diversifications [39, 43, 46, 48, 50, 51]. The negative relationship for education indicates literate farmers are less likely to diversify farm activities where they are liable to engage in off-farm/non-farm livelihood strategies.

\section{Crop-livestock diversification and household food security nexus}

F-statistics for linear regression was significant at $1 \%$, implying that the crop-livestock activities included in the model were jointly significant in influencing the dependent variable -food energy. The value of $R^{2}$ is 0.304 . This means that $30.4 \%$ of the variation in food energy was explained by farm activities included in the model. Substantial differences were existed among households for food energy, as they have pursued diverse crop-livestock activities. Results showed that barley, wheat, and faba bean positively influence food energy, while vegetables and highland fruits had a negative influence on food 
energy at $1 \%$ (Table 5). Households with more croplands for barley, wheat and faba bean were more likely to have better food energy in terms of calories. On the other hand, a negative influence of vegetable production and highland fruits on food energy showed that households with higher fruits and vegetables are less food secure.

\section{Conclusions and policy recommendations}

Diversified farms remain a source of income, risk reduction strategy, and means of livelihoods for smallholders. Crop production and animal husbandry are the two subsystems in the broad mixed crop-livestock system. This study aimed to examine determinants of crop-livestock diversification and the effect of crop-livestock activities on household food energy in central highlands of Ethiopia. The study used cross-sectional data to find out farmers' decision on crop-livestock diversity. Food balance sheet was employed to measure food energy. The study included demographic, economic, institutional, biophysical, topographic and social factors to investigate croplivestock diversification decisions.

Table 5 OLS results on household food energy in calories

\begin{tabular}{|c|c|c|c|}
\hline Farm activities & Coef. & $t$ value & $p$ value \\
\hline Cow & -184.748 & -0.621 & 0.535 \\
\hline Ox & 233.853 & 1.379 & 0.169 \\
\hline Bull & 246.277 & 0.563 & 0.574 \\
\hline Heifer & -93.087 & -0.173 & 0.863 \\
\hline Calf & 916.771 & 0.642 & 0.521 \\
\hline Horse & 457.177 & 1.119 & 0.265 \\
\hline Mule & 1488.291 & 1.537 & 0.126 \\
\hline Donkey & -563.249 & -1.414 & 0.159 \\
\hline Sheep & -297.408 & -1.154 & 0.250 \\
\hline Goat & $-1454.018^{*}$ & -1.679 & 0.095 \\
\hline Chicken & 1745.954 & 0.609 & 0.543 \\
\hline Bee colonies & 21.672 & 0.399 & 0.690 \\
\hline Barley & $1618.349^{* * *}$ & 2.874 & 0.005 \\
\hline Wheat & $3522.539 * * *$ & 4.245 & 0.000 \\
\hline Faba bean & $2359.257^{* * *}$ & 3.754 & 0.000 \\
\hline Field pea & $-1128.296^{*}$ & -1.868 & 0.063 \\
\hline Lentil & -16.441 & -0.022 & 0.983 \\
\hline Linseed & -1118.350 & -0.392 & 0.695 \\
\hline Potato & 1221.641 & 1.191 & 0.235 \\
\hline Vegetables & $-5858.333^{* * *}$ & -2.793 & 0.006 \\
\hline Highland fruits & $-162.991^{* * *}$ & -3.746 & 0.000 \\
\hline -cons & $1905.135^{* * *}$ & 5.363 & 0.000 \\
\hline$R^{2}$ & 0.304 & & \\
\hline Adjusted $R^{2}$ & 0.227 & & \\
\hline$F$ & 3.933 & & \\
\hline N & 211 & & \\
\hline
\end{tabular}

***, **, ${ }^{*}$ are significant at 1,5 and $10 \%$, respectively
The results of descriptive statistics revealed that the majority of farmers produced on average 8.76 types of crop-livestock activities per household. Margalef index of diversity showed a wide variation between zero to one with a mean value of 0.57 attributed to household resources, farmers' preference, ability to manage farm activities, and other natural factors. Crop-livestock diversifiers have better socioeconomic and demographic characteristics compared to non-diversifiers. The Tobit results showed that farmers decided to diversify their farm activities with little influence of discrete choices from independent variables, whereas the extent of diversification was influenced mainly by economic factors. Farmers who accessed irrigation land, more livestock and extension contact were found to have higher level of diversity compared to have-nots. This means that farmers access to more lands from rain-fed and irrigation farming, more livestock and frequent extension support were liable to have higher level of crop-livestock diversities. Conversely, the relationship between land rent-out and crop-livestock diversity was negative and significant, implying that land rent-out reduced both the likelihood and extent of crop-livestock diversity. In addition, results of ordinary least square regression showed that barley, wheat, and faba bean were significant crops that can influence household food energy positively.

The results imply that more farmland, irrigation land, larger livestock, and effective extension service were decisive factors for crop-livestock diversification. Grain crops were the most significant farm activities for household food energy. In conclusion, rain-fed farming supplemented with irrigation and effective agricultural extension services are crucial factors for mixed production. Crop-livestock integration contributes for livelihoods, household food security, and biodiversity conservation. Therefore, among diversified farm activities, grain crops and small ruminants have immense contributions for household food energy. The results of this study suggest that agricultural policies need to assure crop-livestock diversification, which is a means of livelihoods. We also recommend further research on croplivestock diversification to find out the best patterns of diversity so that households can ensure food security and cash incomes.

\footnotetext{
Authors' contributions

WM generated the idea, designed the study, prepared interview schedule, made preliminary survey, and took part in data collection, data entry, data analysis and write up. KM participated in the study design, data analysis, support statistical techniques, and drafted the paper. Both authors read and approved the final manuscript.
}

\section{Author details}

${ }^{1}$ Centre for Rural Development, College of Development Studies, Addis Ababa University, P. o. b 1176, Addis Ababa, Ethiopia. ${ }^{2}$ Crop-Livestock Systems, International Livestock Research Institute, P.o.b 5689, Addis Ababa, Ethiopia. 


\begin{abstract}
Acknowledgements
The authors acknowledge respondent farmers and data collectors. Addis Ababa University, University of Gondar, and Africa RISING project (ILRI) were also acknowledged for their financial support in accomplishing this paper. The content is solely the responsibility of author/s and does not necessarily represent funding organizations.
\end{abstract}

\section{Competing interests}

The authors declare that they have no competing interests.

\section{Availability of data and materials}

Not applicable.

\section{Consent for publication}

Not applicable.

\section{Ethics approval and consent to participate}

Addis Ababa University wrote an official letter to Basona district agricultural office in which the study watershed is located. Anonymity was kept for the study participants.

\section{Funding}

This research was supported by funding from Addis Ababa University, University of Gondar, and Africa RISING project (ILRI).

\section{Publisher's Note}

Springer Nature remains neutral with regard to jurisdictional claims in published maps and institutional affiliations.

Received: 23 March 2018 Accepted: 21 August 2018

Published online: 29 August 2018

\section{References}

1. liyama M, Kaitibie S, Kariuki P, Morimoto Y. The status of crop-livestock systems and evolution toward integration. Ann Arid Zone. 2007;46(3\&4):1-23.

2. Todaro MP, Smith SC. Population growth and economic development: causes, consequences, and controversies. Eleventh ed., Economic developmentBoston: Pearson Addison Wesley; 2012.

3. Asante BO, Villano RA, Patrick IW, Battese GE. Determinants of farm diversification in integrated crop-livestock farming systems in Ghana. Renew Agric Food Syst. 2017. https://doi.org/10.1017/s1742170516000545.

4. Liniger H, Mekdaschi SR, Hauert C, Gurtner M. sustainable land management in practice: guidelines and best practices for Sub-Saharan Africa: field application. Rome: FAO; 2011.

5. Herrero M, Thornton PK, Notenbaert A, Msangi S, Wood S, Kruska R, et al. Drivers of change in crop-livestock systems and their potential impacts on agro-ecosystems services and human wellbeing to 2030. A study commissioned by the CGIAR system wide livestock Programme, Addis Ababa; 2012.

6. Moraine M, Duru M, Nicholas P, Leterme P, Therond O. Farming system design for innovative crop-livestock integration in Europe. Animal. 2014;8(8):1204-17. https://doi.org/10.1017/\$1751731114001189.

7. Berndes G, Bird N, Cowie A. Bio-energy: land use change and climate change mitigation., IEA bioenergyDallas: ExCo; 2010. p. 03.

8. Alexandratos N, Bruinsma J. World agriculture towards 2030/2050: the 2012 revision. ESA Working Paper No. 12-03. FAO: Rome; 2012.

9. Darnhofer I, Gibbon D, Dedieu B. Farming systems research: an approach to inquiry. In: Gibbon D, editor. Farming systems into the 21 st century: the new dynamic. Dordrecht: Springer; 2012. p. 3-31.

10. Kuria A, Lamond G, Pagella T, Aster G, Hadgu K, Sinclair F. Local knowledge of farmers on opportunities and constraints to sustainable intensification of crop-livestock-trees: mixed systems in Lemo Woreda, Southern Nations Nationalities and People Region (SNNPR), Ethiopian highlands. A field study report; 2014. https://cgspace.cgiar.org/bitstream/handl e/10568/41669/Lemo_ARmay.pdf?sequence=1\&isAllowed=y. Accessed 8 Mar 2018
11. Boserup E. The conditions of agricultural growth: the economics of agrarian change under population pressure. Piscataway: Transaction Publishers; 1965.

12. Mclntire J, Bourzat D, Pingali P. Crop-livestock interaction in Sub-Saharan Africa., Regional and sectoral studiesWashington: The World Bank; 1992.

13. Shideed KH, Mohammed EME, editors. Adoption and impact assessment of improved technologies in crop and livestock production systems in the WANA region. The development of integrated crop/livestock production in low rainfall areas of Mashreq and Maghreb Regions (Mashreq/ Maghreb Project). Aleppo: ICARDA; 2005.

14. Manyong VM, Okikeb I, Williamsc T. Effective dimensionality and factors affecting crop-livestock integration in West African savannas: a combination of principal component analysis and Tobit approaches. Agric Econ. 2006;35:145-55

15. IFAD. Integrated crop-livestock farming systems. Livestock thematic papers. Tools for project design. 2010.

16. Alemayehu S, Dorosh P, Sinafikeh A. Crop production in Ethiopia: regional patterns and trends. International Food Policy Research Institute, Ethiopia Strategy Support Program II (ESSP II), Working Paper No. 16. 2011.

17. Lambin EF, Geist HJ, Lepers E. Dynamics of land-use and land-cover change in tropical regions. Annu Rev Environ Resour. 2003;28:205-41. https://doi.org/10.1146/annurev.energy.28.050302.105459.

18. Daniel D. Sustainable land management technologies and approaches in Ethiopia. MoARD; 2010. Addis Ababa, Ethiopia.

19. Godfray HCJ, Beddington RJ, Crute IR, Haddad L, Lawrence D, Muir JF, Pretty J, Robinson S, Thomas SM, Toulmin C. Food security: the challenge of feeding 9 billion people. Science. 2010;327(812):812-8. https://doi. org/10.1126/science.1185383.

20. Belay D, Azage T, Hegde BP. Smallholder livestock production system in Dandi District, Oromia Regional State, Central Ethiopia. Glob Vet. 2012;8(5):472-9.

21. World Bank. Ethiopia's productive safety net program (PSNP) integrating disaster and climate risk management. Case study. 2013.

22. Helina T, Schmidt E. A spatial assessment of livestock production and market access. Summary of ESSP Working Paper 44, "spatial analysis of livestock production patterns in Ethiopia". 2013.

23. Bewket W, Radeny M, Mungai C. Agricultural adaptation and institutional responses to climate change vulnerability in Ethiopia. CCAFS Working Paper No 106. Research Program on Climate Change, Agriculture and Food Security. Copenhagen. 2015.

24. NPC. Growth and transformation plan II (2015/16-2019/20). Vol. I. The main text. Addis Ababa; 2016

25. Thorne MS, Stevenson MH. Stocking rate: the most important tool in the toolbox. Cooperative extension service, College of tropical agriculture and human resources, University of Hawai'i at Manoa. Pasture and range management, PRM-4, 2007.

26. Boserup E. Population and technological change: a study of long-term trends. Chicago: University of Chicago; 1981

27. Eleni Y, Wagner W, Exner-kittridge M, Dagnachew L, Blöschl G. Identifying land use/cover dynamics in the Koga Catchment, Ethiopia, from multi-scale data, and implications for environmental change. ISPRS Int Geo-Inf. 2013;2:302-23. https://doi.org/10.3390/ijgi2020302.

28. IFAD. Smallholders, food security and the environment. 2013.

29. Nigussie H, Atsushi T, Nyssen J, Poesen J, Tsubo M, Dereje D, et al. Soil erosion and conservation in Ethiopia: a review. Prog Phys Geogr. 2015;39(6):750-74. https://doi.org/10.1177/0309133315598725.

30. Tigist B. Assessment of surface water resource and irrigation practices in Gudo Beret Kebele, Amhara Region, Ethiopia. Thesis Presented to Addis Ababa University, Ethiopia. 2016.

31. Mekonnen K, Jogo W, Bezabih M, Mulema A, Thorne P. Determinants of survival and growth of tree lucerne (Chamaecytisus palmensis) in the crop-livestock farming systems of the Ethiopian highlands. Agrofor Syst. 2017. https://doi.org/10.1177/0309133315598725.

32. Lulseged T, Zenebe A, James E, Tesfaye Y, Kifle W, Kindu M, et al. Mapping soil erosion hotspots and assessing the potential impacts of land management practices in the highlands of Ethiopia. Geomorphology. 2017;292:153-63. https://doi.org/10.1016/j.geomorph.2017.04.038.

33. UNEP. Managing increasing pressures on land. Based on GEO-5 land chapter. 2012. 
34. Feder G, Just RE, Zilberman D. Adoption of agricultural innovation in developing countries. A survey. Working Papers No 542. The World Bank, Washington; 1982.

35. Rahm MM, Huffman WE. The adoption of reduced tillage: the role of human capital and other variables. Am J Agric Econ. 1984. p. 405-413

36. Greene W. Econometric analysis. 5th ed. Upper Saddle River: Prentice-hall, Inc.; 2002.

37. Das S, Lyla PS, Khan SA. Marine microbial biodiversity: present status and advanced statistical paradigms. In: McNeely JA, McCarthy TM, Smith A, Olsvig-Whittaker L, Wikramanayake ED. editors. Application of statistical tools: a case study. published by the society for conservation biology asia section and resources himalaya, Kathmandu, Nepal, 2006. p. 455.

38. Margalef R. Information theory in ecology. Int J Gen Syst. 1958; 3:36-71. www.vliz.be/imisdocs/publications/139371on. Accessed 30 Oct 2016.

39. Rehima M, Belay K, Dawit A, Rashid S. Factors affecting farmers' crop diversification: evidence from SNNPR, Ethiopia. Int J Agric Sci. 2013;3(6):558-65.

40. FAO. Livelihood diversification and vulnerability to poverty in Rural Malawi. ASA working paper no 15-02. Rome; 2015.

41. Kibrom T, Krishina V, Qaim M. Production diversity and dietary diversity in smallholder farm households. Proc Natl Acad Sci. 2015;112(34):10657-62. https://doi.org/10.1073/pnas.1510982112.

42. Magurran AE. Measuring biological diversity. Hoboken: Blackwell; 2004.

43. Sichoongwe K, Mapemba L, Ng'ong'ola D, Tembo G. The determinants and extent of crop diversification among smallholder farmers. A case study of southern province, Zambia. Washington: Int Food Policy Res Inst.; 2014. p. 12.

44. Maddala GS. Introduction to econometrics. Second edition, Macmillan publishing company, New York. Maxwell Macmillan Canada, Toronto; Maxwell Macmillan International New York, Oxford, Singapore, Sydney. 1988.

45. Davidson R, Mackinnon JG. Bootstrap testing in nonlinear models. Int Econ Rev. 1999;40(2):487-508.
46. Rahman S, Chima CD. Determinants of food crop diversity and profitability in southeastern Nigeria: a multivariate tobit approach. Agriculture. 2016;6(14):1-14.

47. liyama M, Maitima J, Kariuki P. Crop-livestock diversification patterns in relation to income and manure use: a case study from a rift valley community, Kenya. Afr J Agric Res. 2007;2(3):058-66.

48. Obayelu OA, Akintunde OO, Obayelu AE. Determinants of on-farm cassava biodiversity in Ogun State, Nigeria. Int J Biodivers Sci Ecosyst Serv Manag. 2015;11(4):298-308. https://doi.org/10.1080/21513 732.2015.1071282.

49. Gujarati DN. Basic econometrics. 4th ed. New York: The McGraw-Hili Companies Inc; 2003.

50. Wondimagegn $M$, Bekabil F, Jemal $H$. Pattern trends and determinants of crop diversification: empirical evidence from smallholders in Eastern Ethiopia. J Econ Sustain Dev. 2011;2(8):78-90.

51. FAO-WFP. Joint guidelines for crop and food security assessment missions, Rome; 2009.

52. Robin B. Grains post-harvest loss assessment in Ethiopia: final report. Working Paper No 2377; 1998. http://gala.gre.ac.uk/10758. Accessed on 10 Nov 2017.

53. Dube L, Guveya E. Factors influencing crop diversification: a case study of Manicaland and Masvingo Provinces in Zimbabwe. Int J Reg Dev. 2016;3(2):1-25. https://doi.org/10.5296/ijrd.v3i2.9194.

54. Ashfaq M, Hassen S, Ceer NR, Baig MZ, Asma J. Factors affecting farm diversification in rice-wheat. Pak J Agric Sci. 2008;45(3):91-4.

55. Daniel A, Ali DS, Gautam M. Property rights in a very poor country: tenure insecurity and investment in Ethiopia. World Bank. Policy research. Working Paper No 4363. 2007.

56. Otsukan K. Strategy for agricultural growth in Ethiopia. Briefing note prepared for the DFID funded study "understanding the constraints to continued rapid growth in Ethiopia: the role of agriculture". 2008.
Ready to submit your research? Choose BMC and benefit from:

- fast, convenient online submission

- thorough peer review by experienced researchers in your field

- rapid publication on acceptance

- support for research data, including large and complex data types

- gold Open Access which fosters wider collaboration and increased citations

- maximum visibility for your research: over $100 \mathrm{M}$ website views per year

At BMC, research is always in progress.

Learn more biomedcentral.com/submissions 